\title{
Evaluating choroidal thickness in diabetic retinopathy
}

\author{
Chee Yee Chan' \\ Thanos D Papakostas ${ }^{2}$ \\ Demetrios G Vavvas ${ }^{2}$ \\ 'Department of Ophthalmology, \\ ${ }^{2}$ Retina Service, Massachusetts Eye \\ and Ear Infirmary, Harvard Medical \\ School, Boston, MA, USA
}

\author{
This article was published in the following Dove Press journal: \\ Clinical Ophthalmology \\ 24 June 2014 \\ Number of times this article has been viewed
}

\section{Dear editor}

We read with interest the article by Unsal et $\mathrm{al}^{1}$ and congratulate them on their work assessing choroidal thickness in patients with diabetic retinopathy. We will like to highlight some factors of relevance.

Unsal et al state that their measurement of the choroid was from the outer part of the retinal pigment epithelial layer to the choroidal scleral junction. ${ }^{1}$ However, their Figure 2 seems to draw the upper border of the choroid at various locations (external limiting membrane, inner/outer segment junction, top of the retinal pigment epithelium). ${ }^{1}$ An illustrative diagram (Figure 1) for measuring choroidal thickness can be seen in the study reported by Copete et al. ${ }^{2}$ Recent studies of the thickness of the retinal pigment epithelium-Bruch's membrane complex in normal individuals ranged from $17.5 \mu \mathrm{m}$ to $28.2 \mu \mathrm{m} .{ }^{3}$ Hence, measurement of choroidal thickness has to be drawn correctly and consistently at the same location (outer part of the retinal pigment epithelium) to minimize potential inaccuracies.

It is also important to consider the effects of diurnal variation in choroid thickness on their reported results. Previous studies have concluded that the choroid is found to be thickest at night $(11 \mathrm{pm})$ and thinnest at noon $(12 \mathrm{pm}) .{ }^{4}$ The difference between the thickest and thinnest choroidal thickness due to diurnal variation can be up to $67 \mu \mathrm{m} .{ }^{5}$ Hence, the study could have standardized the timings of the optical coherence tomography scans for both controls and diabetic subjects to minimize any potential differences in choroidal thickness caused by diurnal variation.

The results reported by Unsal et al are consistent with those of other studies showing no significant change in choroidal thickness in subjects with nonproliferative diabetic retinopathy and decreased choroidal thickness in subjects with proliferative diabetic retinopathy or diabetic macular edema. ${ }^{6,7}$ In addition, a recent study by Adhi et al characterized the morphological features of the choroid, ie, the Haller, Sattler, and choriocapillary layers. Their results showed significant thinning of the combined thickness of the Sattler and choriocapillary layers in eyes with proliferative diabetic retinopathy or diabetic macular edema when compared with controls. ${ }^{7}$ It will be interesting to note if similar results were seen in the Unsal et al study too, since both studies used spectral domain optical coherence tomography.

In conclusion, Unsal et al has provided very useful information on choroidal thickness in diabetics. However, measurements of choroid thickness have to be correctly drawn and consideration of diurnal variation is required to improve the accuracy of the results.
Correspondence: Chee Yee Chan Department of Ophthalmology, Massachusetts Eye and Ear Infirmary, 243 Charles Street, Boston, 021 I4, MA, USA

Tel +I 6175733240

Fax + I 6175734324

Email drchenziyi100@gmail.com 


\section{Disclosure}

All authors contributed to, wrote, or edited this letter. The authors have no proprietary or financial interests in its contents.

\section{References}

1. Unsal E, Eltutar K, Zirtiloglu S, Dincer N, Ozdogan Erkul S, Gungel H. Choroidal thickness in patients with diabetic retinopathy. Clin Ophthalmol. 2014;8:637-642.

2. Copete S, Flores-Moreno I, Montero JA, Duker JS, Ruiz-Moreno JM. Direct comparison of spectral-domain and swept-source OCT in the measurement of choroidal thickness in normal eyes. Br J Ophthalmol. 2014;98:334-348.

3. Karampelas M, Sim DA, Keane PA, et al. Evaluation of retinal pigment epithelium-Bruch's membrane complex thickness in dry agerelated macular degeneration using optical coherence tomography. $\mathrm{Br} J$ Ophthalmol. 2013;97:1256-1261.
4. Chakraborty R, Read SA, Collins MJ. Diurnal variations in axial length, choroidal thickness, intraocular pressure, and ocular biometrics. Invest Ophthalmol Vis Sci. 2011;52:5121-5129.

5. Tan CS, Ouyang Y, Ruiz H, Sadda SR. Diurnal variation of choroidal thickness in normal, healthy subjects measured by spectral domain optical coherence tomography. Invest Ophthalmol Vis. 2012;53:261-266.

6. Regatieri CV, Branchini L, Carmody J, Fujimoto JG, Duker JS. Choroidal thickness in patients with diabetic retinopathy analyzed by spectraldomain optical coherence tomography. Retina. 2012;32:563-568.

7. Adhi M, Brewer E, Waheed NK, Duker JS. Analysis of morphological features and vascular layers of choroid in diabetic retinopathy using spectral-domain optical coherence tomography. JAMA Ophthalmol. 2013;131:1267-1274.
Clinical Ophthalmology

\section{Publish your work in this journal}

Clinical Ophthalmology is an international, peer-reviewed journal covering all subspecialties within ophthalmology. Key topics include: Optometry; Visual science; Pharmacology and drug therapy in eye diseases; Basic Sciences; Primary and Secondary eye care; Patient Safety and Quality of Care Improvements. This journal is indexed on

\section{Dovepress}

PubMed Central and CAS, and is the official journal of The Society of Clinical Ophthalmology (SCO). The manuscript management system is completely online and includes a very quick and fair peer-review system, which is all easy to use. Visit http://www.dovepress.com/ testimonials.php to read real quotes from published authors. 